\title{
Determination of the Trophic State Index (TSI) using remote sensing, bathymetric survey and empirical data in a tropical reservoir
}

\author{
Iris Amati Martins ${ }^{1, *}$, Danielle Fein², Marcelo Luiz Martins Pompêo ${ }^{1}$ and Marisa Dantas \\ Bitencourt ${ }^{1}$
}

${ }^{1}$ Department of Ecology, University of São Paulo, Brazil. Rua do Matão, trav. 14, no 321, Cidade Universitária, ZIP code: 05508-090, São Paulo - SP, Brazil.

2 Departament of Biology, FMU Education Group - Laureate International Universities, Brazil. Rua Taguá, $\mathrm{n}^{\circ}$ 150, Liberdade, ZIP code: 01508-010, São Paulo - SP, Brazil.

* Corresponding author: imartins@ib.usp.br

Received: 31/07/18 Accepted: 18/07/19

\begin{abstract}
Determination of the Trophic State Index (TSI) using remote sensing, bathymetric survey and empirical data in a tropical reservoir
\end{abstract}

The reservoirs are important freshwater reserves that suffer with domestic and industrial wastes, causing qualitative and quantitative changes in their physicochemical composition, as well as causing fauna and flora impacts. One of the consequences is eutrophication, a process characterized by increased concentration of nutrients in aquatic ecosystems, mainly phosphorus and nitrogen. In order to classify waterbodies according to their trophic degrees, chlorophyll- $a$ and phosphorus concentration data are usually obtained in water samples, feeding an equation to obtain the Trophic State Index (TSI). The method used at the present work aim to determine the TSI based on remote sensing (RS), by using the ratio between the near-infrared (NIR) and red (RED) images to infer the chlorophyll-a concentration in wet and dry seasons. This method allows a synoptic vision of the reservoir, providing support for decision-making process at low cost, especially when a large amount of data is available and/or generated, increasing quality in consonance with technological development. However, we need to consider the influence of the bottom of shallow areas when using orbital images to evaluate the waterbodies conditions, since the emerging radiation of the euphotic zone is responsible for the results reliability. Thus, it is necessary the exclusion of shallow areas, which may compromise the spectral response of the satellite images due to the bottom effects, before the development of the TSI RS Map. We created the TSI RS Maps (observed) and then we validated it with the Empirical TSI Maps (expected), obtained in 28 geo-coded points along the riverine-transition-lacustrine gradient, both for wet and dry season. We performed the chi-square test that shows how much difference exists between the observed and the expected. Both seasons presented $\mathrm{x}^{2}=1, \mathrm{df}=27$, with critical value $(0.005)$ of 49.64. Therefore, we found no differences between the observed and the expected. Our results reinforce the potentiality of the RS to perform the TSI favoring the identification of eutrophic areas in inland water systems with low turbidity.

Key words: limnology, chlorophyll- $\alpha$, phosphorus, Secchi depth, satellite images, euphotic zone, bottom effects, cascade reservoirs, inland water

\section{RESUMO}

Determinação do Índice de Estado Trófico (IET) por meio de Sensoriamento Remoto, Levantamento Batimétrico e Dados Empíricos em um Reservatório Tropical

Os reservatórios são importantes reservas de água doce que sofrem com despejos de esgotos domésticos e industriais que causam mudanças quantitativas e qualitativas na sua composição físico-química, além de causar impactos na fauna e na flora. Uma das consequências é a eutrofização, processo que se caracteriza pelo aumento na concentração de nutrientes no ecossistema aquático, principalmente fósforo e nitrogênio. A concentração de clorofila-a e de fósforo são obtidas das amostras da água para alimentar as equações de Índice de Estado Trófico (IET). Os métodos usados no presente trabalho visam determinar o grau de trofia utilizando o sensoriamento remoto orbital (SR), que usa a razão entre as imagens das faixas do infravermelho 
(IVP) próximo e do vermelho (VERM) para inferir a concentração de clorofila-a, bem como a variação do IET, no periodo seco e chuvoso. Este método permite uma visão sinóptica que possibilita um suporte para tomada de decisão com baixo custo, especialmente quando um grande volume de dados é disponibilizado elou gerado, ampliando assim a qualidade em função do desenvolvimento tecnológico. Contudo, é necessário considerar a influência do fundo dos corpos d'água quando imagens de satélite são utilizadas, uma vez que a radiação emergente da zona eufótica é que dá respaldo aos resultados. Desde modo, nós excluímos as áreas rasas que pudessem comprometer a resposta espectral das imagens de satélite devido ao efeito do fundo, antes de serem usadas para produzir o Mapa de IET SR. Nós criamos o mapa de IET SR (observado) e então o validamos pelo Mapa de IET Empírico (esperado), obtido por meio de análises químicas realizadas na água em 28 pontos georreferenciados ao longo do gradiente lacustre-fluvial, ambos para o periodo seco e chuvoso. Nós realizamos o teste chi-quadrado que apresenta quanta diferença existe entre o observado e o esperado. Ambos períodos apresentaram $x^{2}=1, \mathrm{gl}=27, \mathrm{com}$ valores críticos (0.005) de 49.64. Desse modo, não encontramos diferenças entre o observado e o esperado. Nossos resultados reforçam a potencialidade do SR na obtenção do IET, favorecendo a identificação de áreas eutróficas em sistemas de águas continentais que apresentam baixa turbidez.

Palavras chave: limnologia, clorofila- $\alpha$, fósforo, profundidade de Secchi, imagens de satélite, zona eufótica, efeito de fundo, reservatórios em cascata, águas continentais

\section{INTRODUCTION}

The planet Earth has two thirds of its surface covered by water, however more than $98 \%$ of available water is salty and only $2 \%$ is freshwater (low salinity), which more than $68 \%$ are distributed in glaciers, $29 \%$ are in deep groundwater reservoirs that are difficult to access, and only $1.2 \%$ is available in rivers and lakes (Senra, 2001). In Brazil, freshwater availability can be considered generous, accounting for $12 \%$ of the planet's water reserves (Senra, 2001), with a surface water production of $168790 \mathrm{~m}^{3} / \mathrm{s}$ (Novaes, 2000). According to the São Paulo State Secretary for Water Supply, about $86 \%$ of the territory of São Paulo State is in the Paraná river basin. The public drinking water supply for the Metropolitan Region of São Paulo (MRSP) is a very important issue due to its population of 17.2 million, distributed along 39 municipalities (EMPLASA, 2000). The Cantareira System, or Cantareira Complex, is a water supply system within the MRSP, which comprises five interconnected reservoirs (Cascade Reservoirs), ending (downstream) in the Juqueri River Reservoir (also known as Paiva Castro Reservoir) and Águas Claras Reservoir, before reach the Water Treatment Plant (WTP Guaraú).

The eutrophication comprises a suite of symptoms that reservoirs exhibit in response to fertilization with nutrients (Hutchinson, 1973). These symptoms include several physical-chemical and ecological alterations listed in the limnological literature (Straškraba, 1999; Cooke et al., 2005; Jørgensen et al., 2005; Jacoby et al., 2007; Schindler et al., 2008; Tundisi \& Tundisi, 2008). The eutrophication arises from the oversupply of nutrients in aquatic ecosystems, mainly phosphorus $(\mathrm{P})$ and nitrogen $(\mathrm{N})$, resulting in increased productivity (Esteves, 2011), which leads to overgrowth of plants and algal blooms that can form masses, floating islands or algal mats that can be displaced by the winds and accumulate on the margins, where its begin to decompose and cause unpleasant smell and production of toxic substances (Branco, 1986). Because of this process, the aquatic ecosystem changes from oligotrophic and mesotrophic to eutrophic or even hypertrophic conditions (Esteves, 2011). To classify the eutrophic state of a reservoir some parameters can be used: total $\mathrm{P}$ and total N, chlorophyll- $a$ concentration, and Secchi disk depth (Andreoli et al., 2011). It is also very common the use of Trophic State Index (TSI), which is an important indicator in the decision-making process concerning the reservoir management. The Carlson (1977) TSI was adapted by Lamparelli (2004) in order to fulfill tropical specification, evaluating water quality related to nutrient enrichment and its effect on excessive algae growth and increased infestation of aquatic macrophytes. Nowadays it is the index used regularly by the official agencies (CETESB, 2013).

Another method to estimate the TSI is those based on satellite images, which can be of great 
help for decision makers since it allows a synoptic view of the reservoir trophic state. The first attempts to apply remote sensing (RS) to monitoring the eutrophication process date from the 1970s, but the remote sensors available at the time were not suitable to the complexity of inland waters (George \& Malthus, 2001). With the improvement and the popularization of the satellite imagery along the last decades, several other TSIs were proposed (Novo, 2007). Yacobi et al. (2011); Gitelson et al. (2011), Dall'Olmo \& Gitelson (2005), Gons et al. (2002), Gitelson \& Kondratyev (1991) suggested that red (RED) and near-infrared (NIR) spectral responses can be particularly helpful to estimate chlorophyll- $a$ concentration in eutrophic waterbody, where Colored Dissolved Organic Matter (CDOM) are abundant. Duan et al. (2007) studied Changan Lake, northeast China, demonstrated the efficiency of the ratio between NIR and RED to estimate chlorophyll- $a$ concentration. Novo et al. (2013) proposed recently a new TSI using orbital remote sensing in Ibitinga Reservoir, part of Tietê River dam complex, located in the geographic center of the São Paulo State in the Middle Tietê River Valley. Using Monte Carlo simulation, the authors selected the most suitable model relating to chlorophyll- $\alpha$ concentration and simulated $\mathrm{TM} /$ Landsat reflectance. The ratio between NIR (TM4) and RED (TM3) provided the best model with a $\mathrm{R}^{2}$ value of 0.78 , enhancing the relationship between chlorophyll- $a$ concentration and remotely sensed reflectance, since the high concentration of phytoplankton increases the reflectance in the NIR and decreases the reflectance in the RED. However, it is necessary to consider the effects of the reservoir bottom in shallow areas, which may compromise the information contained in the satellite images, being sure that the emerging radiation used to calculate the TSI comes exclusively from the euphotic zone (Kirk, 2011; Bitencourt \& Mantelli, 2015).

As the costs for conventional limnological monitoring (water sampling and laboratory analysis) are high, it is important and often necessary to use monitoring methods that seek to reduce costs, in addition to optimize acquisition results. The use of new data sources and spatial analysis tools, such as RS and geoprocessing, can contribute to reducing costs, since there are satellite images and geoprocessing software packages that are free. The RS also allows an efficient and constant acquiring of data sets along the time and space, contributing with the decision-making process in the water resources management.

The main objective of this paper is to produce a TSI Map using Remote Sensing (observed) according to Novo et al. (2013) and validate it with an Empirical TSI Map (expected) performed by using field data (concentrations of chlorophyll- $a$ and total P), for both wet and dry seasons in the Paiva Castro Reservoir. To achieve that objective, it was necessary to make some maps using models already presented in the literature and/or to create new other maps. The reservoir bathymetry map, for example, had to be created. Therefore, bathymetric field data should be sampled and analyzed beforehand. Therefore, the flowchart for bathymetry is a brand-new way of obtaining such map and the description step by step can very helpful to further decision makers. Other flowcharts are also presented to help decision makers, but they are not of our complete authorship even though they show the step by step to generate each thematic map used as the basis for development of the TSI maps, and the steps to generate the TSI maps itself. Each step was carefully examined and justified in order to improve confidence. We hope to reinforce the potentiality of the Remote Sensing data (RS) to perform the TSI in tropical reservoirs, also acquiring some important limnologic parameters like chlorophyll- $a$ concentration, Secchi depth and euphotic zone extension, in different space and time scales depending of the resolution of the remote sensor.

\section{MATERIALS AND METHODS}

\section{Study Area}

The Paiva Castro is the fifth downstream reservoir of the Cantareira System just before Águas Claras Reservoir where the water is treated to become drinkable. The System was concluded in 1973 (Figs. 1 and 2). Its watershed comprises 33 715 ha, mainly composed by native forest, herbaceous vegetation and forestry, with little 


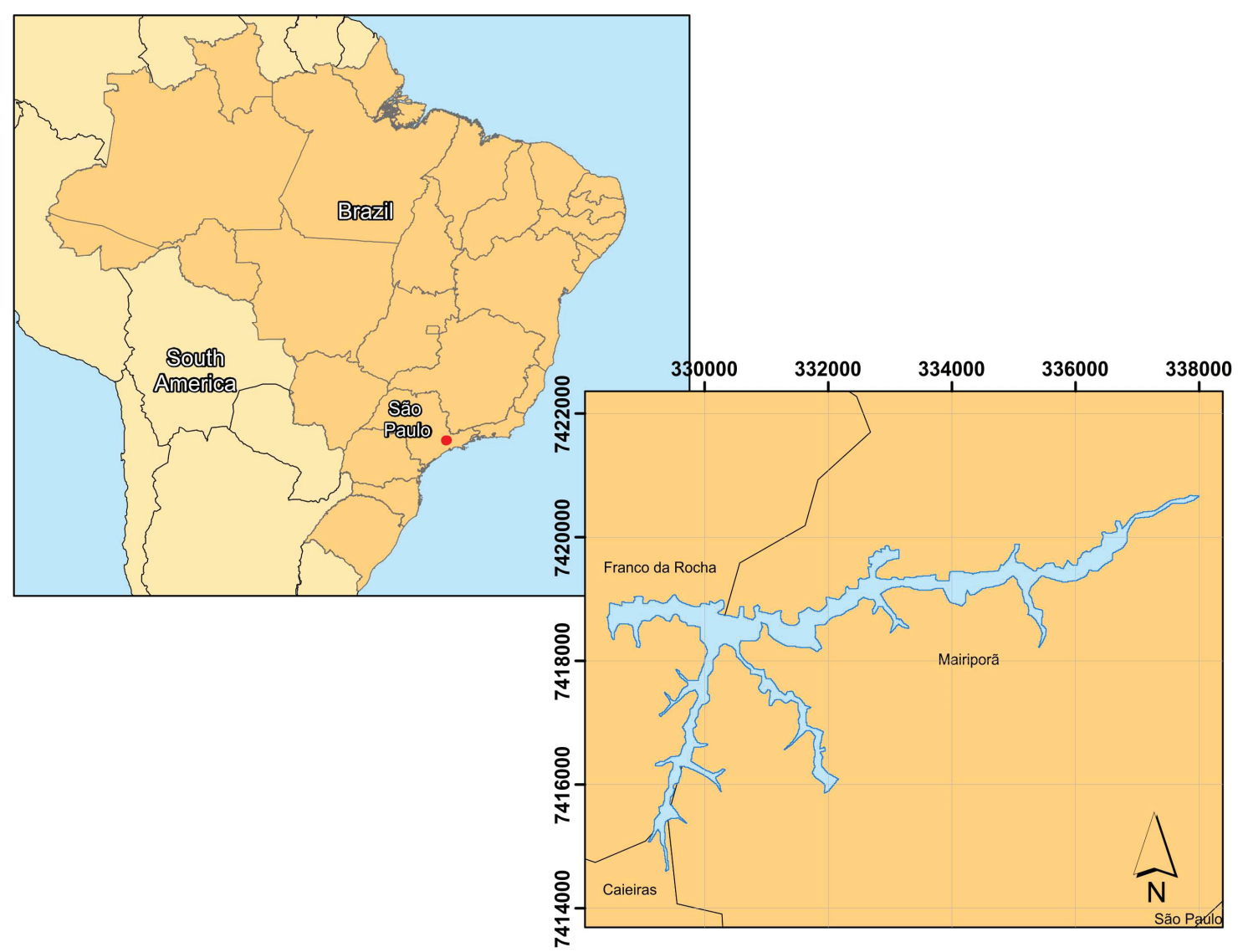

Figure 1. The location of the Paiva Castro Reservoir. Localização do Reservatório Paiva Castro.

influence of urban areas. The reservoir contributes with $6.1 \%$ of the whole Cantareira System water production. Its surface area comprises 445 ha and the retention time is 14 days, which characterizes the Paiva Castro Reservoir more lotic than lentic.

\section{Bathymetric Survey}

To obtain the bathymetric map of the reservoir we had three days of field work using a marine Geographical Position System (GPSMAP GARMIN 421S) coupled with a transducer to get $\mathrm{X}$ and $\mathrm{Y}$ coordinates and the reservoir depth. To check error positions, we used a Differential Global Positioning System (DGPS), GNSS Sf3040-Rtk-Sfto receptor. To get $Z$ elevation and to determine and evaluate the errors of $\mathrm{X}$ and $\mathrm{Y}$ positions, we used the software R (2008). Further analyses were performed in order to obtain the final elevation model.

\section{Remote Sensing (RS)}

To develop the Euphotic Zone Map and the TSI RS Map we used Landsat 5 - Thematic Mapper (TM) images from two dates: January 9th and May 1rst 2009, wet and dry season respectively. We selected those dates due to the proximity with the period in which the empirical data sampling was performed and because of the absence of clouds. We obtained the images from the Brazilian National Institute for Space Research (INPE) catalog (INPE, 2016). We used the reservoir polygon obtained through bathymetric survey to constrain the reservoir area in the Landsat images. 
Using the software Terrset (Eastman, 2015), we performed the processing of the Landsat images aiming to minimize the Rayleigh scattering effects (atmospheric correction). The method of atmospheric correction was the Total Correction Model (Eastman, 2015), which includes the parameters used in the Dark Object Subtraction Model (DOS) and the Cos (t) Model developed by Chavez (1996). We also performed the radiometric correction aiming to correct the radiometric degradations due to mismatches in the calibration of the detectors and errors in the data transmission, a procedure that ensures that changes in spectral behavior, both in time and in space, are strictly related to the interaction of the electromagnetic radiation with the target, eliminating contributions of the environment in the reflectance of the target (Moreira, 2012).

\section{Empirical Data}

We used as empirical data the georeferenced data sampled by Macedo (2011) in 28 points along the riverine-transition-lacustrine gradient of the Paiva Castro Reservoir, at wet season (November 2008) and dry season (June 2009). She determined the total $\mathrm{P}$ and chlorophyll- $a$ concentration by spectrophotometry (Wetzel \& Likens, 1991; Valderrama, 1981), and the Secchi depth by Secchi disk.

\section{Euphotic Zone Mask}

The euphotic zone mask aims to constraint the area of analysis in the satellite images avoiding the bottom effects of shallow areas. Thus, we used the ratio between BLUE (TM2) and TM4 images to obtain the Secchi depth (Pereira et al., 2011). The next step was the development of the euphotic zone image based on Esteves (2011), Bukata et al. (1995), and Kirk (2011). We performed a logical operation to create a mask that excluded the shallow areas of the reservoir. If the extension of the euphotic zone was equal or more than depth obtained by the bathymetric survey, the area equivalent was excluded. If the extension of the euphotic zone was less than depth, the area equivalent was included, i.e., the area that will be the object to performing TSI RS. We present here a flowchart that shows the step by step to obtain the euphotic zone mask.

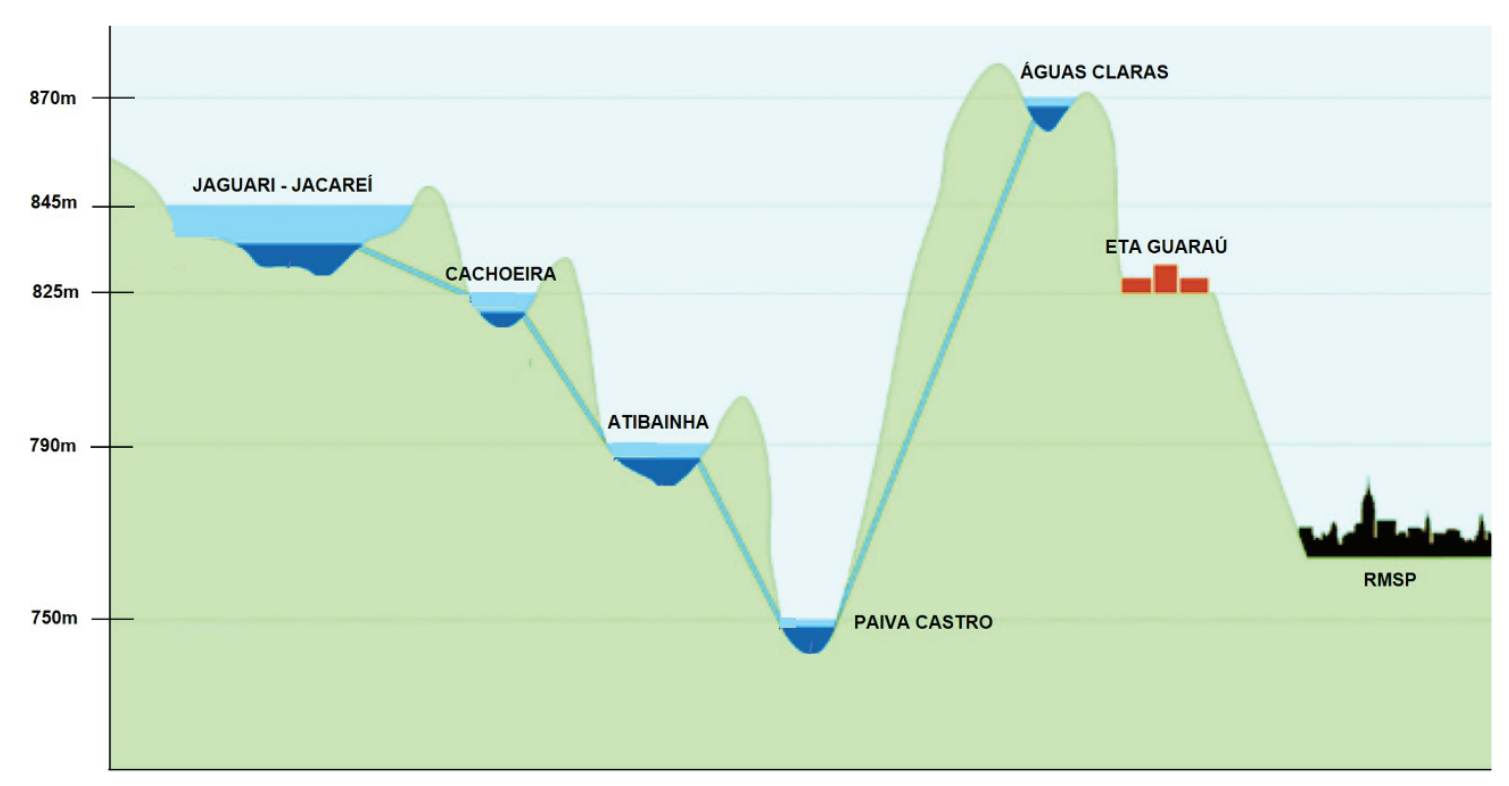

Figure 2. The Cantareira System (adapted from ANA, 2013). ETA: Estação de Tratamento de Água (Water Treatment Plant); RMSP: Região Metropolitana de São Paulo (Metropolitan Area of Sao Paulo). The Y-axis represents the altitude. O Sistema Cantareira (adaptado de ANA, 2013). ETA: Estação de Tratamento de Água; RMSP: Região Metropolitana de São Paulo. O eixo Y representa a altitude. 


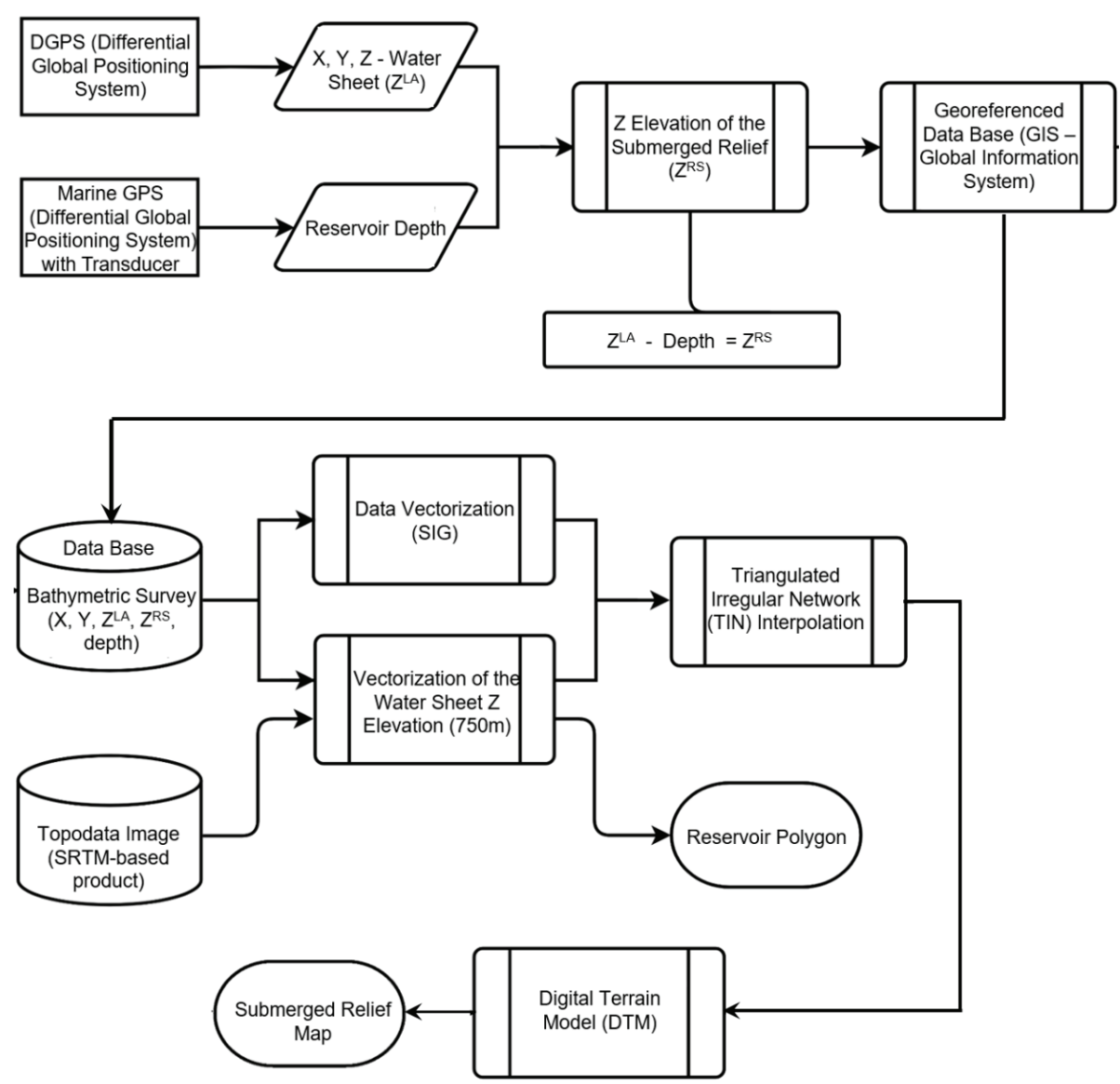

Figure 3. Flowchart showing the steps to perform the bathymetric survey. Fluxograma apresentando as etapas para o desenvolvimento do levantamento batimétrico.

\section{Trophic State Index (TSI)}

To obtain the TSI Map using RS for wet and dry seasons, we used the TM4 and TM3 images from Landsat 5. We applied the euphotic zone mask to these images to eliminate the shallow areas and consequently the bottom effects within the spectral response registered by satellite images. Therefore, we used the model based on the TM4/TM3 ratio proposed by Novo et al. (2013) to obtain the chlorophyll-a concentration. Afterwards, we calculated the Lamparelli (2004) TSI and then we classified the TSI in the following classes: ultraoligotrophic $($ TSI $<47)$, oligotrophic $(47<$ TSI $\leq$ $52)$, mesotrophic $(52<\mathrm{TSI} \leq 59)$, and eutrophic $(59<\mathrm{TSI} \leq 63)$, producing the TSI RS Maps.

To develop the Empirical TSI Map firstly we calculated the Lamparelli (2004) TSI using the concentrations of chlorophyll- $a$ and total $\mathrm{P}$ obtained in water samples for both seasons. As the water samples are geocoded, we performed the TIN interpolation of the TSI values and then we converted the resulting polygons into a surface image. Thereafter, we classified the Empirical TSI image in the following classes: ultraoligotrophic (TSI < 47), oligotrophic $(47<$ TSI $\leq 52)$, mesotrophic $(52<\mathrm{TSI} \leq 59)$, and eutrophic $(59<$ $\mathrm{TSI} \leq 63)$, resulting in an Empirical TSI Maps.

\section{Geostatistical}

We validated the TSI RS Maps (observed) toward the Empirical TSI Maps (expected). We performed the validation in two ways: (a) using 
the chi-square test, that shows how much difference exists between the observed and the expected; (b) using a Contingency Table or Error Matrix, where the columns represent the reference data or the data that is known to be true (empirical), and the rows are the classes that were mapped and generated from the RS data. Doing so, we obtained the Kappa Index in order to evaluate the concordance of the classification (Congalton \& Mead, 1991).

\section{RESULTS}

The bathymetric survey was performed in four stages: (a) the first stage resulted from three

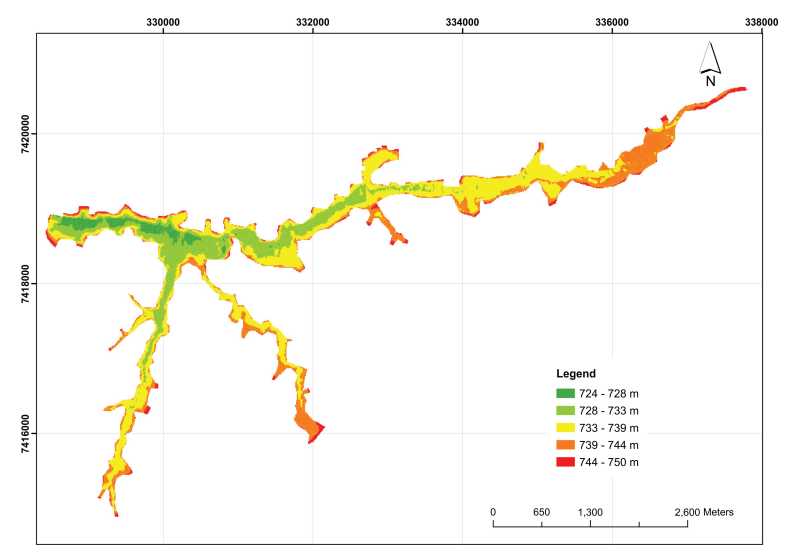

Figure 4. Submerged Relief Map. Mapa do Relevo Submerso.

Table 1. Comparison between field values and remote sensing values for Secchi Depht $(\mathrm{m})$ and Euphotic Zone (m). Comparação entre os valores de campo e os valores obtidos por sensoriamento remoto para a profundidade de Secchi (m) e Zona Eufótica (M).

\begin{tabular}{|c|c|c|c|c|c|c|c|c|c|c|}
\hline \multirow{3}{*}{ ID } & \multirow{2}{*}{\multicolumn{2}{|c|}{$\begin{array}{c}\text { UTM Coordinates } \\
\text { (Datum WGS84, 23K) }\end{array}$}} & \multicolumn{4}{|c|}{ Secchi Depht (m) } & \multicolumn{4}{|c|}{ Euphotic Zone (m) } \\
\hline & & & \multicolumn{2}{|c|}{ Field Values } & \multicolumn{2}{|c|}{ RS Values } & \multicolumn{2}{|c|}{ Field Values } & \multicolumn{2}{|c|}{ RS Values } \\
\hline & $\mathrm{X}$ & $\mathrm{Y}$ & Dry & Wet & Dry & Wet & Dry & Wet & Dry & Wet \\
\hline $\mathrm{P} 2$ & 337360 & 7420431 & 1.27 & 1.20 & 2.13 & 2.24 & 3.42 & 3.25 & 5.75 & 6.05 \\
\hline P3 & 336906 & 7420283 & 1.27 & 1.20 & 2.65 & 2.63 & 3.42 & 3.25 & 7.16 & 7.10 \\
\hline $\mathrm{P} 4$ & 336669 & 7419810 & 1.27 & 1.20 & 2.38 & 2.56 & 3.42 & 3.25 & 6.43 & 6.91 \\
\hline P6 & 335866 & 741950 & 1.16 & 1.10 & 2.58 & 2.57 & 3.13 & 2.97 & 6.97 & 6.94 \\
\hline $\mathrm{P} 7$ & 335466 & 7419404 & 1.06 & 1.18 & 2.65 & 2.68 & 2.86 & 3.19 & 7.16 & 7.24 \\
\hline P8 & 335102 & 7419506 & 0.94 & 0.95 & 2.65 & 2.65 & 2.54 & 2.57 & 7.16 & 7.16 \\
\hline P9 & 334722 & 7419326 & 1.00 & 1.15 & 2.65 & 2.62 & 2.70 & 3.11 & 7.16 & 7.07 \\
\hline P10 & 334356 & 7419371 & 0.92 & 1.13 & 2.64 & 2.69 & 2.48 & 3.05 & 7.13 & 7.26 \\
\hline P11 & 333952 & 7419253 & 0.92 & 1.14 & 2.65 & 2.65 & 2.48 & 3.08 & 7.16 & 7.16 \\
\hline P12 & 333553 & 7419297 & 0.85 & 1.18 & 2.66 & 2.66 & 2.30 & 3.19 & 7.18 & 7.18 \\
\hline P13 & 333104 & 7419243 & 0.90 & 1.07 & 2.63 & 2.67 & 2.43 & 2.89 & 7.10 & 7.21 \\
\hline P14 & 332671 & 7419204 & 0.75 & 1.22 & 2.65 & 2.65 & 2.03 & 3.29 & 7.16 & 7.16 \\
\hline P15 & 332373 & 7418951 & 0.92 & 1.01 & 2.64 & 2.67 & 2.48 & 2.73 & 7.13 & 7.21 \\
\hline P16 & 331990 & 7418795 & 0.91 & 1.13 & 2.63 & 2.66 & 2.46 & 3.05 & 7.10 & 7.18 \\
\hline P17 & 331652 & 7418499 & 1.05 & 0.93 & 2.65 & 2.68 & 2.84 & 2.51 & 7.16 & 7.24 \\
\hline P20 & 330637 & 7418484 & 1.65 & 1.17 & 2.65 & 2.68 & 4.46 & 3.16 & 7.16 & 7.24 \\
\hline $\mathrm{P} 21$ & 330246 & 7418640 & 1.33 & 1.32 & 2.64 & 2.67 & 3.59 & 3.56 & 7.13 & 7.21 \\
\hline P22 & 329880 & 7418714 & 1.76 & 1.32 & 2.64 & 2.64 & 4.75 & 3.56 & 7.13 & 7.13 \\
\hline $\mathrm{P} 23$ & 329562 & 7418891 & 2.18 & 1.17 & 2.64 & 2.65 & 5.89 & 3.16 & 7.13 & 7.16 \\
\hline P24 & 329208 & 7418849 & 2.19 & 1.38 & 2.65 & 2.64 & 5.91 & 3.73 & 7.16 & 7.13 \\
\hline P26 & 328532 & 7418942 & 2.37 & 1.46 & 2.65 & 2.68 & 6.40 & 3.94 & 7.16 & 7.24 \\
\hline P27 & 330191 & 7418257 & 1.31 & 1.07 & 2.64 & 2.68 & 3.54 & 2.89 & 7.13 & 7.24 \\
\hline P28 & 330113 & 7417901 & 1.18 & 1.22 & 2.64 & 2.67 & 3.19 & 3.29 & 7.13 & 7.21 \\
\hline P29 & 329986 & 7417565 & 1.18 & 1.27 & 2.28 & 2.21 & 3.19 & 3.43 & 6.16 & 5.97 \\
\hline P30 & 329895 & 7417203 & 1.13 & 1.44 & 2.59 & 2.53 & 3.05 & 3.89 & 6.99 & 6.83 \\
\hline P32 & 329728 & 7416921 & 1.17 & 1.37 & 2.65 & 2.66 & 3.16 & 3.70 & 7.16 & 7.18 \\
\hline P33 & 329522 & 7416068 & 1.17 & 1.52 & 2.68 & 2.12 & 3.16 & 4.10 & 7.24 & 5.72 \\
\hline
\end{tabular}




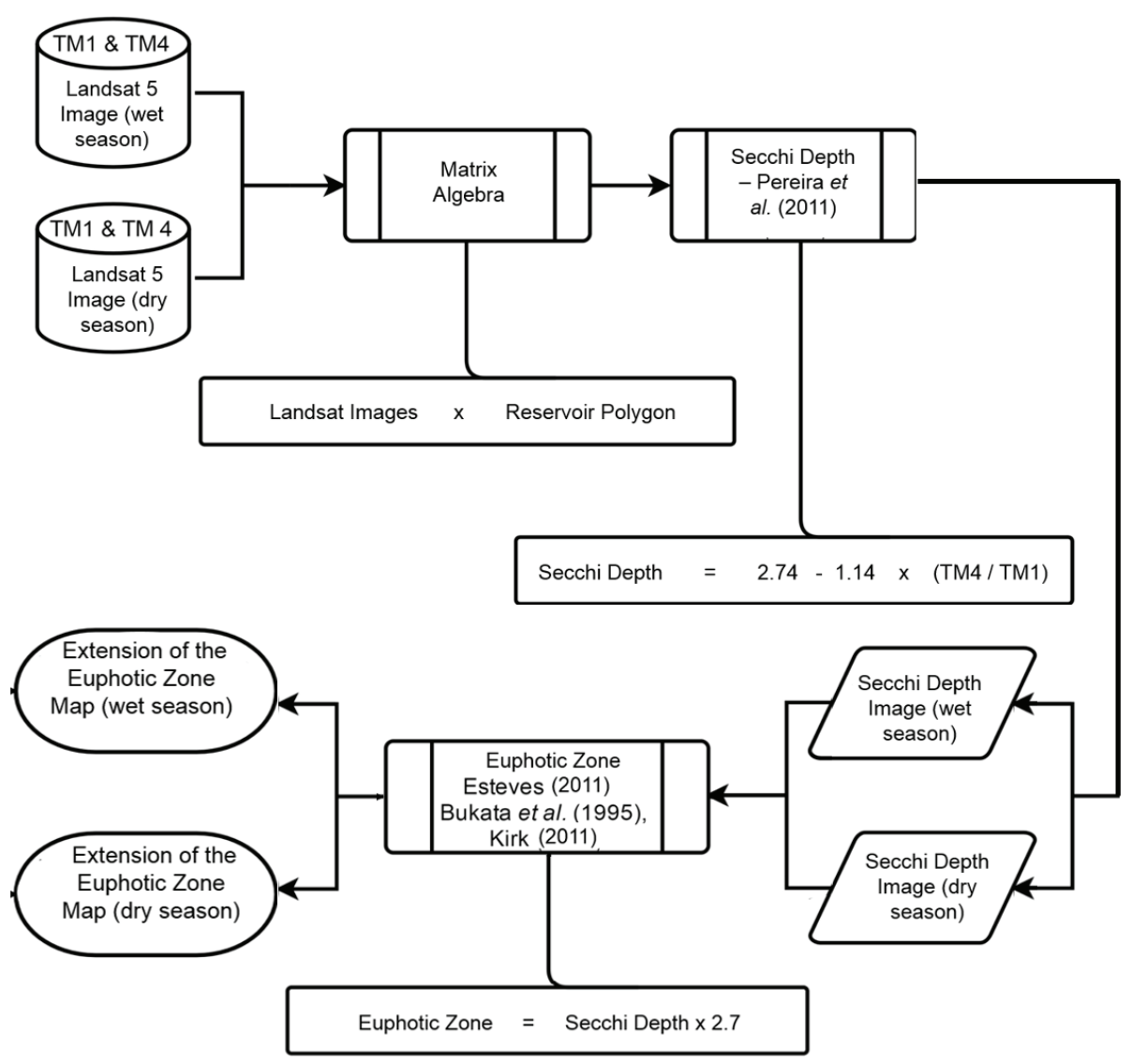

Figure 5. Flowchart showing the steps to perform the Euphotic Zone Map. Fluxograma apresentando as etapas de desenvolvimento do Mapa de Zona Eufótica.

days of field work, using a marine GPS with transducer installed in the boat and a DGPS; (b) the second stage was the pre-processing of sampled data, associating the information of the marine GPS with the DGPS and analyzing the difference between the $\mathrm{X}$ and $\mathrm{Y}$ axes; (c) the third stage comprises the interpolation of the sampling data by using the Triangulated Irregular Network (TIN) and the conversion into surface (Martins, 2017); and (d) the fourth stage occurred during three more days of field work, aiming to complete the bathymetric survey, fulfilling the gaps of the previously survey. Finally, 16529 points were sampled along the reservoir of approximately $4.49 \cdot 106 \mathrm{~m}^{2}$. We determined the sample sufficiency with $1 \%$ margin of error and $99 \%$ confidence interval. To perform the sampling, the boat bordered the entire reservoir and then crossed two parallel lines along the reservoir. The next step was to make a zigzag from margin to margin. We recorded the data every $10 \mathrm{~m}$ with the boat stopped to obtain information from the marine GPS and DGPS.

The data distribution of the first bathymetric survey allows us to detect that the differences between the marine GPS and DGPS. The results were the constancy between the $\mathrm{X}$ and $\mathrm{Y}$ axes, except to a few outliers $(0.75 \%$ of the surveyed points) that we excluded based on the mean and standard deviation. The creation of the bathymetric function $\left(\operatorname{Bat}_{\mathrm{f}(\mathrm{x})}=\mathrm{X}-40\right.$ and $\left.\mathrm{Bat}_{\mathrm{f}(\mathrm{y})}=\mathrm{Y}-44\right)$, allow us to adjustment of the $\mathrm{X}$ and $\mathrm{Y}$ axes for further surveys and to model the submerged relief.

After pre-processing the data using bathymet- 
ric function, the data were TIN interpolated and converted them into a surface image. At this stage, the information related to the $\mathrm{Z}$ elevation value from the reservoir water level was recorded.

The bathymetric survey also allows us to obtain the reservoir polygon, considering the almost constant surface level of $750 \mathrm{~m}$ of altitude. That polygon we used to constraint the satellite images to perform all the geospatial analyses. The Figure 3 presents the flowchart of all steps to obtain the bathymetric survey. The Figure 4 reveals the submerged relief map.

The Secchi depth values found using RS were quite homogeneous along de reservoir ranging from $2.6 \mathrm{~m}$ to $2.7 \mathrm{~m}$ mainly in the central portion of the reservoir and at the border the values were near to $2.0 \mathrm{~m}$. We did not observe differences between wet and dry seasons although, the results of the empirical Secchi depth, shows a high amplitude along the reservoir, 17 times higher than RS values in wet season and 9 times higher in dry season (Table 1).

We created the Euphotic Zone Maps using the Secchi depth (SD) images obtained with RS (Fig. 5). We did not observed differences between the wet and dry season in areas that have the extension of the euphotic zone until 3 $\mathrm{m}$. On the other hand, areas with the euphotic zone extension between 4-5 m present an increase of $51.2 \%$ in the dry season, while areas with the euphotic zone extension within the range of $7 \mathrm{~m}$ decreases in the dry season $(8.1 \%)$

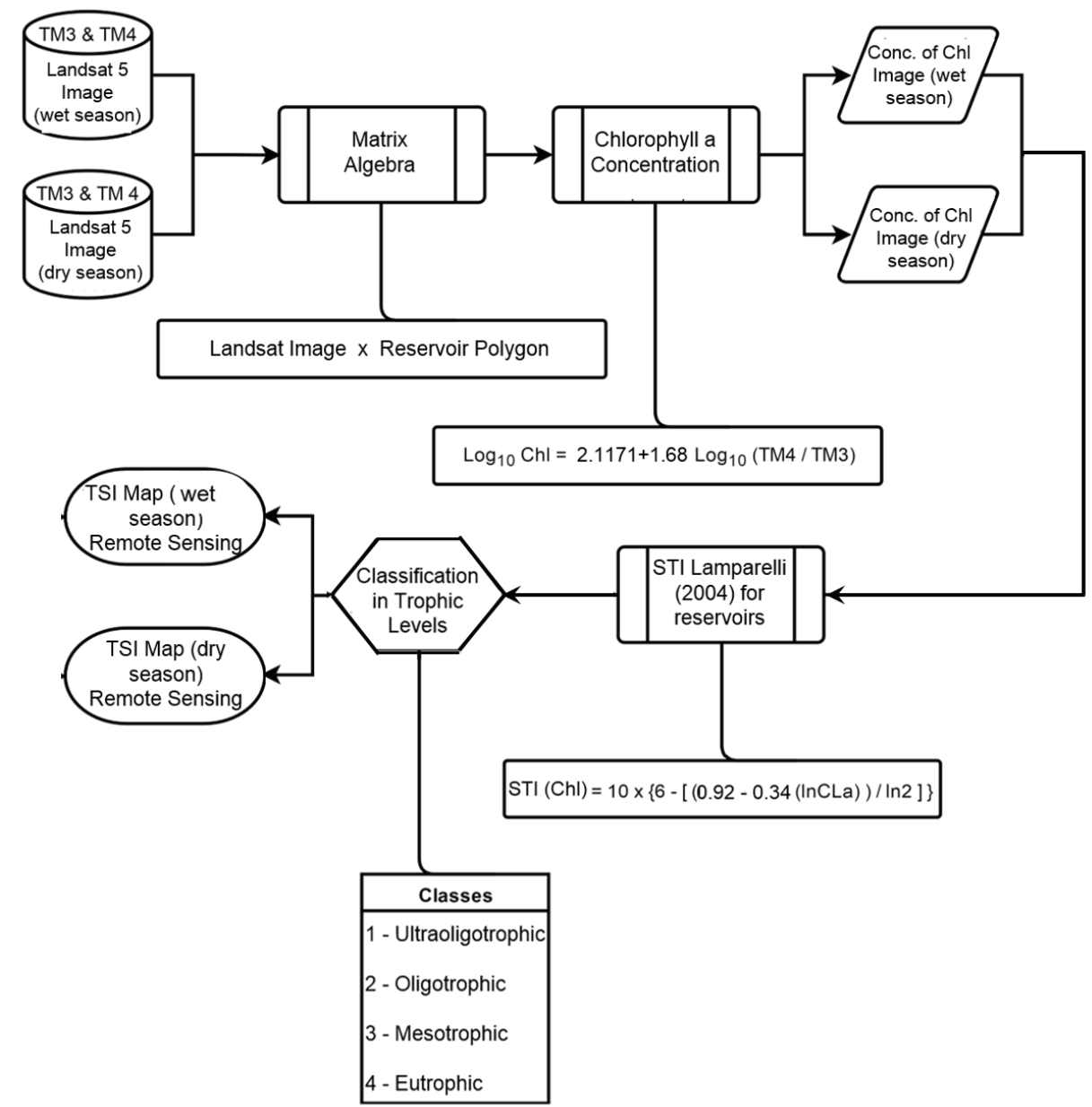

Figure 6. Flowchart showing the steps to perform the TSI Remote Sensing Map. Fluxograma apresentando as etapas de desenvolvimento do Mapa de IET produzido por sensoriamento remoto. 


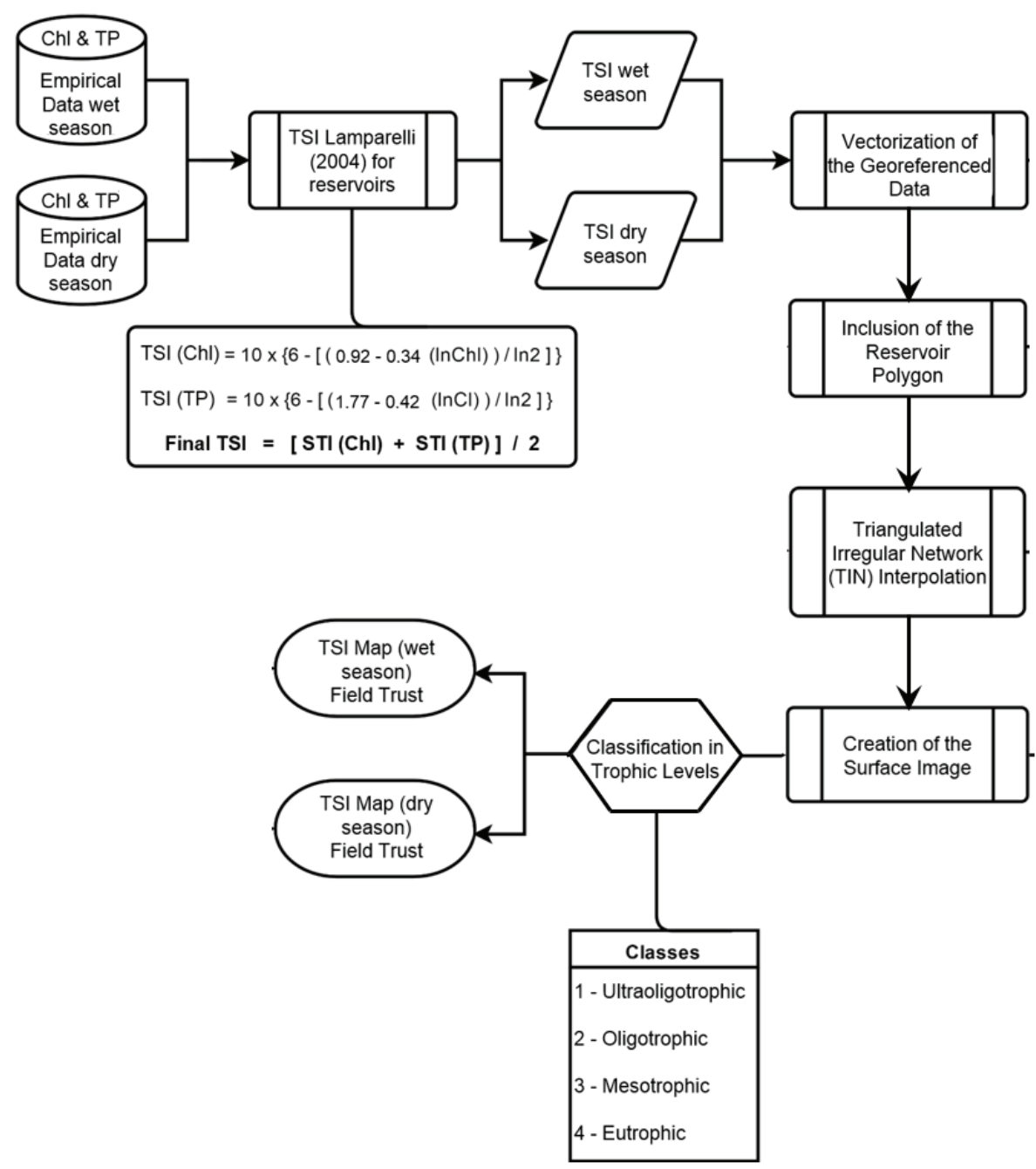

Figure 7. Flowchart showing the steps to perform the TSI Empirical Map. Fluxograma apresentando as etapas de desenvolvimento do Mapa de IET Empírico.

(see Table 1). The euphotic zone mask, that we create to constraint the area to perform the TSI RS, excluded $11.5 \%$ of the pixels (51.5 ha) to avoid the bottom effects of shallow areas. We did not observed differences between the wet and dry season.

We create the TSI RS Maps and the Empirical TSI Maps as shown in Figure 6 and Figure 7, respectively. The resulting maps represents the TSI obtained by SR (Fig. 8) and the TSI obtained empirically, using the chlorophyll- $\alpha$ and Total $\mathrm{P}$ data (Fig. 9). Both maps comprise mainly the mesotrophic class in both periods. The dry season presents an increasing of values classified into the mesotrophic class, followed by a decrease of values located into the oligotrophic class, indicating an increase of trophic degree from wet to dry season. When we compared the TSI RS Maps (observed) with the Empirical TSI Maps (expected) we found no significant differences between the observed and the expected for both seasons $\left(x^{2}=1\right.$, df $=27$, with critical value $(0.005)$ of 49.64). The Kappa Index also validate the TSI RS, since the Kappa Index was reasonable $(0.2180)$ for the wet season and very good $(0.6250)$ for the dry season. 

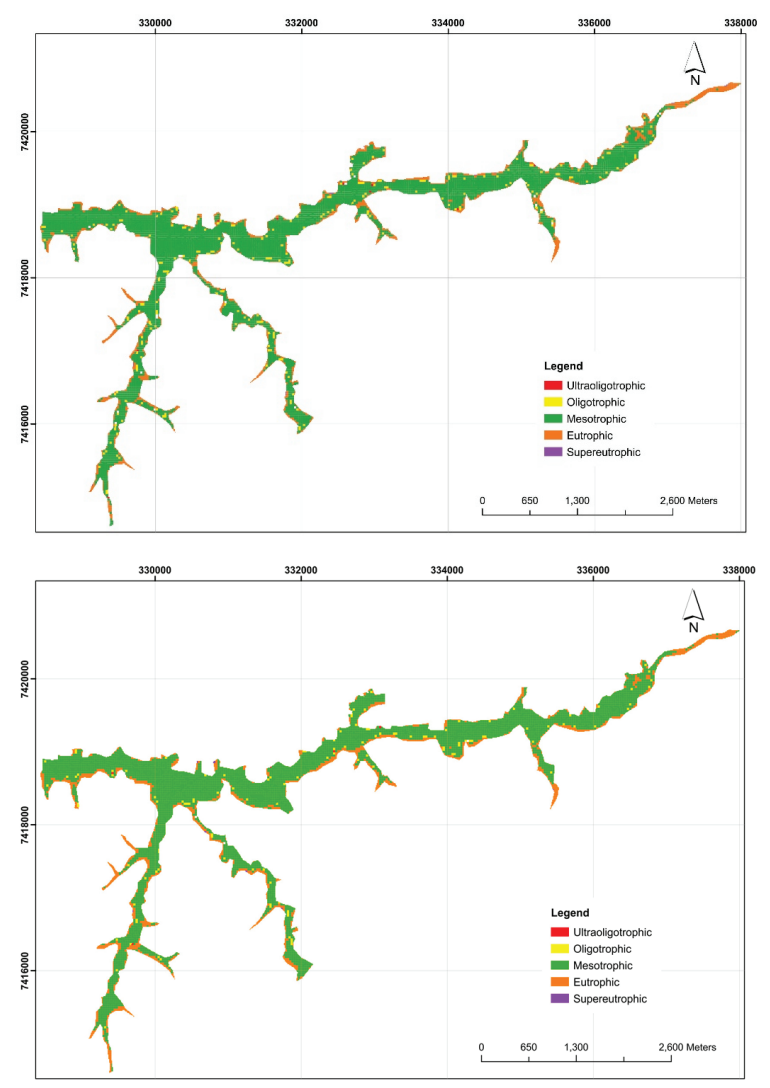

Figure 8. The TSI RS Map: a) dry season; b) wet season. Mapa de IET produzido por sensoriamento remoto: a) estação seca; b) estação chuvosa.

\section{DISCUSSION}

Our goal was to show ways to use orbital remote sensing data to determine the trophic state degree in an artificial reservoir, diminishing the costs of data acquisition and optimizing the monitoring of reservoirs. The bathymetric map was obtained using field survey and geoprocessing techniques. We also developed a series of flowcharts that presents the step by step to obtain all maps used here to model the Trophic State Index.

The bathymetric survey allows us to model the submerged relief, to delimit the reservoir polygon, and to create the euphotic zone mask by acquiring the $\mathrm{X}$ and $\mathrm{Y}$ coordinates, the $\mathrm{Z}$ elevation of the water surface, and the reservoir depth, within an adequate scale and accuracy to limno- logic studies. The altimetry variation of $25 \mathrm{~m}$, observed in the Relief Map is related to the preterit use of the reservoir area (sand mining), before the dam construction in the 1960's.

We obtained a homogeneous distribution of Secchi depth values along the reservoir in agreement with Pereira et al. (2011). They did not find relevant differences between the values obtained by RS of those obtained in situ, as we found in the present work. We expect to find some differences because the radiance within each pixel comprises the mean radiance of an area that varies with the spatial resolution of the satellite, whereas the field measurement is only one human observation. Therefore, the RS is much more reliable in obtaining the Secchi depth considering the limitations related to the spatial scale, whereas the Secchi depth is an inference and not a direct measure.

The use of euphotic zone mask is found to be necessary to avoid the undesirable bottom effect always present in RS data. The shallow areas must be erased because only the water within the euphotic zone can be related to limnologic parameters. Depending on the reservoir geomorphology the shallow waters can be significant or not. In this case they may not be significant, but we decide to maintain the mask in the flowchart to alert about its importance. The differences between the wet and dry season is perfectly understandable because the precipitation within the watershed during the wet season may strongly improve the turbidity. Ngabirano et al. (2016) also observed low turbidity during the dry season in reservoirs located in Uganda. They related the difference between both seasons as a decrease of concentration of small clay minerals particles, dissolved colored compounds and colloids in dry season.

However, it does not seem to be the case in our reservoir because it occurs in the plateau with Litolics rock outcrops, Cambisols, Yellow Red Latosol, and Podzolic Red Yellow soils. Analyzing Figure 2, it is possible to understand why the Paiva Castro reservoir is so peculiar: it is hilly, showing few shallow areas; it is the fifth reservoir of the Cantareira System, and it is kept in an almost constant water level along the seasons. The land used within its watershed (area of about 33690 ha) comprises an urban areas (Mairiporã city) and some disperse human occupation $(1.7 \%)$, water of 
various type $(1.6 \%)$, cultivate forest $(3.9 \%)$, semi natural fields $(33.4 \%)$, and semi natural forest (59.4\%), according to Martins (2017) and Kumazawa $C$ (2018).

The TSI RS Map produced here was geostatistical validated, whereas no significant differences were found between the observed (TSI RS) and the expected (Empirical TSI). Our results agree with Novo et al. (2013) about the TM4/TM3 ratio being appropriate to cover a large range of chlorophyll- $a$ concentration and, consequently, to access a broad of trophic states degrees, favoring the identification of eutrophic areas in inland water systems with low turbidity. The TM4/TM3 ratio is the best input variable to estimate the chlorophyll-a concentration since the absorption peak occurs in $670 \mathrm{~nm}$ (RED) and the spectral reflectance peak (fluorescence and phytoplankton cell backscattering) occurs in $700 \mathrm{~nm}$ (NIR) besides this ratio mitigates the effects of the atmospheric and water surface reflectivity on the measurements performed by the satellite sensors (Novo et al., 2013; Duan et al., 2007).

\section{CONCLUSION}

We found that the bathymetric survey is necessary to model the submerged relief. We strongly advise the exclusion of the shallow areas before use satellite images (SR) to infer any limnologic parameters within the euphotic zone. We assumed that the Secchi depth obtained by SR tends to be more reliable because each pixel reveals the mean value of a bigger area than the observed in the field. The high concentration of chlorophyll- $a$, one of the symptoms of eutrophication, can be detected and measured by using satellite images due to the interaction between the pigment and the electromagnetic radiation. Thereby, it is possible to acquire a large amount of data, in several scales, that is useful to determine the trophic degrees in reservoirs. The strength of the RS relies on the easy access of information, in different space and time scales, and the acquisition of images can be without cost in some governmental agencies' website. Our results showed that RS can be reliable providing the information necessary to obtain the TSI and reinforces the potentiality of the RS to predict limnologic parameters in different space and time scales.

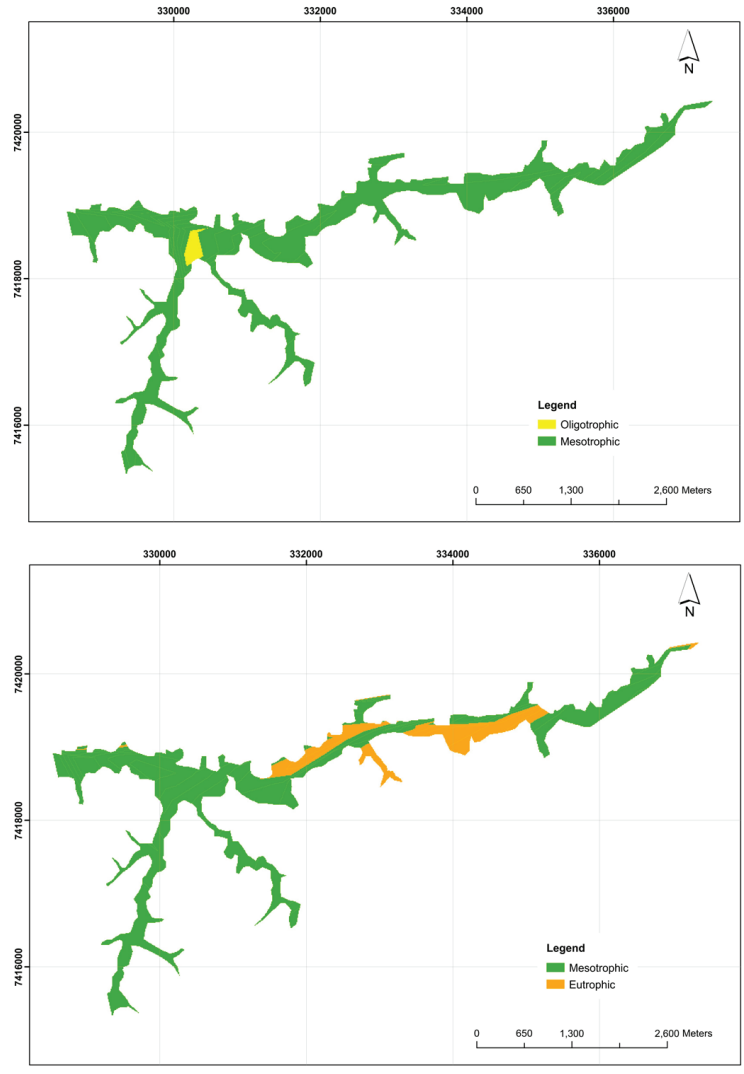

Figure 9. The TSI Empirical Map: a) dry season; b) wet season. Mapa de IET Empírico: a) estação seca; b) estação chuvosa.

\section{ACKNOWLEDGEMENTS}

We would like to thank the University of São Paulo (USP) for the institutional support, the São Paulo Research Foundation (FAPESP) for financial support, and the Coordination for the Improvement of Higher Education Personnel (CAPES) for the scholarship support. We also thank Dr. Sheila Cardoso-Silva for your assistance in data acquisition and helpful comments, and Isis Bazarin Wennrich for improving the maps layout.

\section{REFERENCES}

ANA (Brazil National Water Agency). 2013. Dados de referência acerca da outorga do Sistema Cantareira (Reference data about the 
water use permit of the Cantareira System) (Technical Report). ANA, São Paulo, BR. http://arquivos.ana.gov.br/institucional/ sof/Renovacao_Outorga/DadosdeReferencia AcercadaOutorgadoSistemaCantareira.pdf

ANDREOLI, C. V., C. CARNEIRO, E. F. GOBBI \& C. L. N. CUNHA. 2011. Eutrofização e a estrutura dos estudos (Eutrophication and structure of the studies). In: Eutrofização em reservatórios. Gestão preventiva: estudo interdisciplinar na Bacia do Rio Verde (Eutrophication in reservoirs. Preventive management: an interdisciplinary study in the Rio Verde basin). CUNHA, C. L. N., C. CARNEIRO, E. F. GOBBI, \& C. V. ANDREOLI (eds.): 27-28. Editora UFPR, Paraná, BR. ISBN: 9788573352863.

BITENCOURT, M. D. \& L. R. MANTELLI. 2015. Análise espacial de parâmetros limnológicos utilizando sensoriamento remoto $\mathrm{e}$ geoprocessamento: dois estudos de caso. (Spatial analyses of limnological parameters using remote sensing and geoprocessing: two case studies). In: Ecologia de Reservatórios e Interfaces (Reservoir Ecology and Interfaces). POMPEO, M. L. M., V. MOSCHINI-CARLOS, P. Y. NISHIMURA, S. C. SILVA, J. C. LOPEZ-DOVAL (eds.): 160-176. Instituto de Biociências da Universidade de São Paulo, São Paulo, BR. DOI: 10.11606/9788585658526

BRANCO, S. M. 1986. Hidrobiologia aplicada à engenharia sanitária (Hydrobiology applied to sanitary engineering). Editora CETESB, São Paulo, BR.

BUKATA, R. P., J. H. JEROME, K. Y. KONDRATYEV \& D. V. POZDNYAKOV. 1995. Optical Properties and Remote Sensing of Inland and Coastal Waters. CRC Press, Florida, US. DOI: 10.1201/9780203744956

CARLSON, R. E. 1977. A trophic state index for lakes. Limnology \& Oceanography, 22 (2):361-369. DOI: 10.4319/1o.1977.22.2.0361

CETESB (Environmental Company of Sao Paulo State). 2013. Qualidade das águas superficiais no estado de São Paulo (Surface water quality in the São Paulo State) (Technical Report). CETESB, São Paulo, BR. https://cetesb. sp.gov.br/aguas-interiores/wp-content/uploads/ sites/12/2013/11/relatorio-aguas-superficiais2013-parte1.pdf

CHAVEZ, P. S. Jr. 1996. Image-based atmospheric corrections: Revisited and improved. Photogrammetric Engineering and Remote Sensing, 62:1025-1036.

COOKE, G. D., E. B. WELCH, S. A. PETERSON \& S. A. NICHOLS. 2005. Restoration and Management of Lakes and Reservoirs, CRC Press, Florida, US. DOI: 10.1201/ 9781420032109

CONGALTON, R. G. \& R. A. MEAD. 1991. A review of assessing the accuracy of classification of remote sensed data. Remote Sensing of Environment, 37(1):35-46. DOI: 10.1016/00344257(91)90048-B

DALL'OLMO, G. \& A. GITELSON. 2005. Effect of bio-optical parameter variability on the remote estimation of chlorophyll- $a$ concentration in turbid productive waters: experimental results. Applied Optics, 44(20):412-422. DOI: 10.1364/AO.44.000412

DUAN, H., Y. ZHANG, B. ZHANG, K. SONG \& Z. WANG. 2007. Assessment of Chlorophyll- $a$ Concentration and Trophic State for Lake Chagan Using Landsat TM and Field Spectral Data. Environmental Monitoring and Assessment, 129:295-308. DOI: 10.1007/ s10661-006-9362-y

EMPLASA (Metropolitan Planning Company of the São Paulo State). 2000. Metrópoles em Dados (Metropolis in data) (Technical Report). EMPLASA, São Paulo, BR. www.emplasa.sp.gov.br

ESTEVES, F. A. 2011. Fundamentos da limnologia (Fundamentals of Limnology). Interciência. Rio de Janeiro, BR. ISBN: 9788571932715.

EASTMAN, J. R. 2015. Terrset Tutorial. Clark University. Massachusetts, US. https://clarklabs. org/wp-content/uploads/2016/10/TerrSetTutorial.pdf

GEORGE, D. G. \& T. J. MALTHUS. 2001. Using a compact airborne spectrographic imager to monitor phytoplankton biomass in series of lakes in north Wales. The Science of the Total Environment, 268:215-226. DOI: 10.1016/S0048-9697(00)00694-X

GITELSON, A. A. \& K. Y. KONDRATYEV. 1991. Optical models of mesotrophic and 
eutrophic water bodies. International Journal of Remote Sensing, 12:373-385. DOI: 10.1080/01431169108929659

GITELSON, A. A., D. GURLIN, W. J. MOSES \& Y. Z. YACOBI. 2011. Remote estimation of chlorophyll-a concentration in inland, estuarine, and coastal waters. In: Advances in Environmental Remote Sensing: Sensors, Algorithms and Applications. Q. Weng (Ed.): 449-478. CRC Press, Florida, US. DOI: 10.1201/b10599-23

GONS, H. J., M. RIJKEBOER \& K. G. RUDDICK. 2002. A chlorophyll-retrieval algorithm for satellite imagery (Medium Resolution Imaging Spectrometer) of inland and coastal waters. Journal of Plankton Research, 24(9):947-951. DOI: 10.1093/plankt/24.9.947

HUTCHINSON, G. E. 1973. Eutrophication. American Scientist, 61:269-279.

INPE (Brazil National Institute for Space Research). 2016. Catálogo de imagens (Images Catalog). http://www.dgi.inpe.br/CDSR/

JACOBY J. M., E. B. WELCH \& T. LINDELL. 2007. Pollutant Effects in Freshwater: Applied Limnology. CRC Press, New York, US. DOI: $10.1201 / 9781482265118$

JØRGENSEN, S. E., H. LÖFfIER, W. RAST \& M. STRAŠKRAB. 2005. Developments in Water Science: Lake and Reservoir Management. Elsevier Science. ISBN: 9780444516787.

KIRK, J. T. O. 2011. Light and Photosynthesis in aquatic Ecosystems. Cambridge University Press. Cambridge, UK. DOI: $10.1017 /$ CBO9781139168212

KUMAZAWA, V. R., M. L. M. POMPEO \& M. D. BITENCOURT. 2018. Atribuição da Tipologia "Geologia" da Diretiva Quadro da Água (DQA) para os reservatórios paulistas do Sistema Cantareira (Attribution of the "Geology" typology of the Water Framework Directive (WFD) for the Cantareira System). Caderno Prudentino de Geografia, Presidente Prudente, 40(2):02-22. ISSN: 2176-57743 3.

LAMPARELLI, M. C. 2004. Graus de trofia em corpos d'água de estado de São Paulo: avaliação dos métodos de monitoramento (Trophic degrees in water bodies located in São Paulo State: evaluation of monitoring methods). Ph.D. Thesis, University of São
Paulo (USP), BR. DOI: 10.11606/T.41.2004. tde-20032006-075813

MACEDO, C. C. L. 2011. Heterogeneidade espacial e temporal das águas superficiais e das macrófitas aquáticas do reservatório Paiva Castro (Spatial and temporal heterogeneity of surface waters and aquatic macrophytes of the Paiva Castro reservoir). Master Dissertation, University of the State of São Paulo (UNESP), BR.

MARTINS, I. A. 2017. Modelagem em SIG da fragilidade ambiental para o processo de eutrofização antrópica em reservatórios tropicais. (A GIS-Based Model to access the environmental fragility to human-induced eutrophication in tropical reservoirs.). Ph.D. Thesis, University of São Paulo (USP), BR. DOI: 10.11606/T.41.2017.tde-25112017154450

MOREIRA, M. A. 2012. Fundamentos do sensoriamento remoto e metodologias de aplicação (Fundamentals of remote sensing and application methodologies). Editora UFV. Minas Gerais, BR. ISBN: 9788572693813.

NGABIRANO, H., D. BYAMUGISHA \& E. NTAMBI. 2016. Effects of seasonal variations in physical parameters on quality of gravity flow water in Kyanamira sub-country, Kabale district, Uganda. Journal of Water Resource and Protection, 8:1297-1309. DOI: 10.4236/jwarp.2016.813099

NOVAES, W. 2000. Agenda 21 brasileira: bases para discussão (Brazilian Agenda 21: basis for discussion). MMA/PNUD. Brasília, BR. ISBN: 85-87166-10-7.

NOVO, E. M. L. M. 2007. Monitoramento de quantidade e qualidade da água e sensoriamento remoto (Monitoring water quantity and quality with remote sensing). Proccedings of the XVII Simpósio Brasileiro de Recursos Hídricos da Associação Brasileira de Recursos Hídricos. November, 25-29, 2007. São Paulo. São Paulo, BR: 1-20.

NOVO, E. M. L. M., L. R. LONDE, C. BARBOSA, C. A. S. ARAUJO \& C. D. RENNÓ. 2013. Proposal for a remote sensing trophic state index based upon TM/Landsat images. Revista Ambiente e Água, 8(3):65-82. DOI: 10.4136/1980-993X 
PEREIRA, A. C. F., M. L. B. T. GALO \& E. D. VELINI. 2011. Inferência da transparência da água - reservatório de Itupararanga/SP, a partir de imagens multiespectrais Ikonos e espectrorradiometria de campo (Inference of water transparency - Itupararanga reservoir / SP, from Ikonos multispectral images and field spectroradiometry). Revista Brasileira de Cartografia, 63(1):179-190. ISSN: 0560-4613

R DEVELOPMENT CORE TEAM. 2008. $R: A$ language and environment for statistical computing. R Foundation for Statistical Computing. Vienna, Austria. http://www.R-project.org

SENRA, J. B. 2001. Água, o desafio do terceiro milênio (Water, the challenge of the third millennium). In: O Desafio da Sustentabilidade: um debate socioambiental no Brasil (The Challenge of Sustainability: a socio-environmental debate in Brazil). VIANA, G., M. SILVA \& N. DINIZ (Org.): 133-144. Fundação Perseu Abamo, São Paulo, Brazil. ISBN: 85864695219788586469527.

SCHINDLER, D. W., R. E. HECKY, D. L. FINDDLAY, M. P. STAITON, B. R. PARKER, M. J. PATERSON, K. G. BEATY, M. LYNG \& S. E. M. KASIAN. 2008. Eutrophication of lakes cannot be controlled by reducing nitrogen input: Results of a 37-year whole-ecosystem experiment. PNAS, 105: 11254-11258. DOI: 10.1073/pnas.0805108105
STRAŠKRABA, M. 1999. Retention time as a key variable of reservoir limnology. In: Theoretical reservoir ecology and its applications. Tundisi, J. \& M. Straškraba (eds):385-410. Brazilian Academy of Sciences and Backhuys Publishers, São Paulo, BR. ISBN: 8587418025.

TUNDISI, J. G. \& T. MATSUMURA-TUNDISI. 2008. Limnologia (Limnology). Editora Oficina de Textos São Paulo. São Paulo, BR. ISBN: 858623866X.

VALDERRAMA, J. G. 1981. The simultaneous analysis of nitrogen and phosphorus in natural waters. Marine Chemistry, 10:109-122. DOI: 10.1016/0304-4203(81)90027-X

YACOBI, Y. Z., W. J. MOSES, S. KAGANOVSKY, B. SULIMANI, B. C. LEAVITT, E. B. WELCH, J. M. JACOBY \& T. LINDELL. 2007. Pollutant Effects in Freshwater: Applied Limnology. CRC Press. New York, US. ISBN: 9780415279918.

YACOBI, Y. Z., W. J. MOSES, S. KAGANOVSKY, B. SULIMANI, B. C. LEAVITT \& A. A., GITELSON. 2011. NIR-red reflectance-based algorithms for chlorophyll- $a$ estimation in mesotrophic inland and coastal waters: Lake Kinneret case study. Water Research, 45(7): 2428-2436. DOI: 10.1016/j.watres.2011.02.002 WETZEL, R. G. \& G. E. LINKENS. 1991. Limnological Analyses. Springer-Verlag. DOI: 10.1007/978-1-4757-3250-4

Con el patrocinio de:

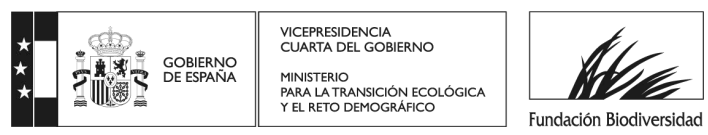

